\title{
Evaluation of Innovation Policy in Kazakhstan in the Period of Globalization Trends
}

\section{Nurbek Achilov*}

G-Global Development Community, Kazakhstan

\begin{abstract}
This paper shortly reviews the theories about innovation and evaluates the ingredients and perspectives of development of innovation policy in Kazakhstan. In the period of implementation of new economic reforms, Kazakhstan focused on extraction and export of natural resources. During realization of state programs, many innovation projects fail. Therefore, paper aims to investigate the main barriers and perspectives by providing policy recommendations for Government of Kazakhstan. In the period of further privatization of state organizations in Kazakhstan and globalization trends, the paper demonstrate a strong necessity for changes in present innovation programs. Understanding that a market capacity for innovation in Kazakhstan is limited, the paper aims to focus on ideas of export-oriented innovations.
\end{abstract}

Keywords: Innovation policy; Growth strategies; Research and development; Innovative entrepreneurship; Export oriented innovation; Globalization trends

\section{Introduction}

Kazakhstan's key innovation policy started with 2010-2014 National Program of forced industrial and innovative development of the Republic of Kazakhstan. It aimed to guarantee a stable and well-balanced economic growth by means of diversification and improvement of Kazakhstan's competitive ability. For realization of this program, allocation of 6.5 trillion budget for respected years were projected in the document [1]

At present, the government implements the State Program on industrial development of the Republic of Kazakhstan for years 20152019 , which aims to promote diversification and competitiveness of the manufacturing industry with the budget of 1717 billion tenge [2].

The primary purpose of these programs are to improve the business environment indicators, increasing the country's competitiveness, reduction of the state involvement in the economy through a planned privatization [3-5]. The Table 1 shows the changes in ranking of Kazakhstan in the rankings during the period of realization of these state programs.

From the table the Doing Business Rank improved from $59^{\text {th }}$ position in 2010 to $41^{\text {st }}$ in 2016, the World Competitiveness Index improved from $72^{\text {nd }}$ position in 2010 to $42^{\text {nd }}$ in 2016 rank and the IMD World Competitiveness Score declined from $33^{\text {rd }}$ position in 2010 to $47^{\text {th }}$ in 2016. It is clear that these rankings cause conflict in concluding the real improvements. Therefore, for review, it is necessary to check statistical data on innovations comparing data for the period of realization these programs (2010-2016).

To illustrate, Table 2 shows the volume of produced innovative products and spending for scientific research in Kazakhstan [6].

According to the table, the year 2014-2015 for both indicators was a period of sharp decline. It confirms that IMD's World Competitiveness Score is more exact and appropriate in evaluation of competitiveness level of Kazakhstan.

From the situation in oil markets, the drop of oil prices in 20142015 decreased demand from many local companies and importers. In addition, Kazakhstan was late to devaluate its currency to Russian Ruble and the other was a massive budget cuts in state organizations of Kazakhstan, which caused in general economic deterioration of all indicators. It is clear that productions should not only focus on innovations for local consumers. That is a key point to focus on international theories and models that will help to rebuild Kazakhstan's innovation policy on development of export-oriented innovations.

However, is it a main criterion to let innovations decrease in volume or in sales? How Kazakhstan categorize innovations and $\mathrm{R} \& \mathrm{D}$ spending and definitions of products and services? These are the questions, which need an in-depth analysis in perspective.

Moreover, it is important to mention that $\mathrm{R} \& \mathrm{D}$ spending of Kazakhstan is around $0.2 \%$ of GDP [7]. In fact, it is a key indicator for showing a level of financing of local individuals and organizations to innovate and develop new products and services. There is no possibility to create a system for development of innovations on a constant level in Kazakhstan when R\&D lacks financing.

In addition, serious economic problems during a period of price decline for natural resources showed that developing innovativeness is much more important factor than focusing on new products manufactured with the help of imported new technologies.

From marketing point, strategies of the national programs of Kazakhstan for bringing innovations and diversification of the economy was too early for local companies and individuals to enter new markets when they had difficulty with operations, product development, R\&D and sales in local markets. Although, companies were renovated their technologies and were ready to supply products for export.

Therefore, initially, National program's priority should have been focusing on product development strategies, which would be able to renovate existing companies gradually based on their own resources

${ }^{*}$ Corresponding author: Nurbek Achilov, Founder, Member of Board, Managing Director, NGO, G-Global Development Community, Kazakhstan, Tel: 77019402978; E-mail: nurbek2020@gmail.com

Received August 03, 2016; Accepted September 13, 2016; Published September 23, 2016

Citation: Achilov N (2016) Evaluation of Innovation Policy in Kazakhstan in the Period of Globalization Trends. Bus Eco J 7: 251. doi: 10.4172/2151-6219.1000251

Copyright: $\odot 2016$ Achilov N. This is an open-access article distributed under the terms of the Creative Commons Attribution License, which permits unrestricted use, distribution, and reproduction in any medium, provided the original author and source are credited. 


\begin{tabular}{|l|l|c|c|}
\hline Rankings & Source & $\mathbf{2 0 1 0}$ \\
\hline Doing Business Rank & World Bank [3] & 59 \\
\hline World Competitiveness Index & World Economic Forum [4] & 72 \\
\hline World Competitiveness Scoreboard & IMD [5] & 41 & 33 \\
\hline \multicolumn{2}{|l|}{ Table 1: The rankings of Kazakhstan in doing business and competitiveness. } \\
\hline
\end{tabular}

Table 1: The rankings of Kazakhstan in doing business and competitiveness.

\begin{tabular}{|l|l|l|l|l|l|}
\hline Years & $\mathbf{2 0 1 0}$ & $\mathbf{2 0 1 1}$ & $\mathbf{2 0 1 2}$ & $\mathbf{2 0 1 3}$ & $\mathbf{2 0 1 4}$ \\
\hline Produced Innovative products & 142166,8 & 235962,7 & 379005,6 & 578263,1 & 580386,0 \\
\hline Scientific-Research Spending & 110,5 & 116,2 & 428,8 & 407,3 & 365,1 \\
\hline
\end{tabular}

Source: Committee of Statistics of the Ministry of National Economy.

Table 2: Statistics on Innovation in Kazakhstan, mln. Tenge.

\begin{tabular}{|l|l|l|l|}
\hline & Current Products & New products & Innovations \\
\hline Current Markets & Market Penetration Strategy & Product Development Strategy & Patent Strategy, Intellectual Rights \\
\hline $\begin{array}{l}\text { New Markets, incl. Export } \\
\text { Markets }\end{array}$ & Market Development Strategies & Diversification Strategies & and Property Protection \\
\hline
\end{tabular}

Table 3: Growth strategies for organizations.

and prepare them for diversification or new market development strategies in the later stages.

On the other side, the role of R\&D is vital in the development of innovations and new industries, which Kazakhstan focuses in its state programs. However, low R\&D financing demonstrate a low-level attention by state bodies. Their focus on importing of technologies for production of products on present high demand was considered developing innovativeness of country. Table 3 shows growth strategies of an organization while developing its markets and new industries.

Generally, Table 3 extends the alternative corporate growth strategies [8] to show the role of $R \& D$ and innovations in a single table. It outlines that the priority of the new state programs could be R\&D and Product Development Strategies as they related to creating not only innovations but also new industries of Kazakhstan. Thus, the National programs should aim to increase financing of R\&D and develop new approaches and directions of activities to reconsider the focuses of its programs.

Understanding that new global competitive environment requires from companies and organization to increase its competitiveness on a constant level, $R \& D$ is a major factor for bringing innovations and new industries of Kazakhstan. It helps also to build industries, which meet the requirements of open borders for global trade, competition and trends.

In addition, according to classical theory [9], "the process of technological change in a free market consists of three parts: invention (conceiving a new idea or process), innovation (arranging the economic requirements for implementing an invention), and diffusion (whereby people observing the new discovery adopt or imitate it)". In this regard, Table 3 shows not only the types of products and the appropriate strategies. Rather it outlines the chain of product development, starting from invention to current product. This is a good point to say that knowledge management systems are necessary and a vital instrument to drive innovation chain on a constant level.

It is clear that not all innovations can become a consumed new product immediately. Most of them go to shelfs to wait their turn. Therefore, statistics of innovative products in Table 2 are not exactly the statistics of innovations. From international business point, these products are existing products for new markets like Kazakhstan. From this, one can conclude that innovations of Kazakhstan are still to come and wait their turn. One reason is a meaning of innovation for Kazakhstan's policy makers and state bodies. As in Table 3, real innovations should start with a number of patents and financing of research and development, which are not easy to find in Kazakhstan's information sources.

This finding is a key to point that the state and corporate programs of Kazakhstan should change and focus on R\&D policy to bring innovations in near future. It will require reconsidering the budgets, technologies and infrastructures for industries where Kazakhstan can take competitive advantage from international trade of patents, new products and services.

However, those who make argument that innovation is the engine of long run economic growth define it broadly not just new products, but also new processes, new organizations, new management practices and new strategies [10]. According to authors of international business, the business environment should be more conducive to the production of innovations. This requires development of economy based on free market, which create more incentives for individuals to make money out of their innovative ideas by starting their own business easily.

In an economy such as in Kazakhstan, where $75 \%$ of GDP comes from the state sector, there is few opportunities for individuals to develop innovations as they see no profits from state strictly managed structures or because of unfair legal systems. The demanding factor for renovation of the policy is innovative entrepreneurship - a new focus for innovation policy programs. This means redirecting financing from state corporate organization to new businesses where innovative entrepreneurs take their leadership role in creating and managing innovations.

Only can innovative entrepreneurs make businesses and economies work for innovations. These leaders can distinguish and form a business culture of a country or a global environment when their products and services will gradually find consumers globally.

Table 4 below shows differences in innovation policy of major export oriented markets based on preliminary analysis of familiar key brands and innovation policies.

The table outlines the options for Kazakhstan government for building its innovation policy based on success of main export oriented markets. When focus is for multiple sectors, it is important for Kazakhstan that entrepreneurial specialists and scientists find their supporters for innovative ideas in and outside the organizations. This 


\begin{tabular}{|c|c|c|c|c|}
\hline & US & Europe & Japan & Korea \\
\hline Main Brands & $\begin{array}{l}\text { Ford, GE, Chevrolet, Apple, IBM, } \\
\text { Shell, Boing, KPMG, John Deer, } \\
\text { McDonalds, Coca-Cola }\end{array}$ & $\begin{array}{l}\text { Mercedes, Siemens, SAP, } \\
\text { Porsche, BMV, Nokia, Airbus, } \\
\text { Adidas, Chanel }\end{array}$ & $\begin{array}{l}\text { Toyota, Sony, Mitsubishi, Honda, } \\
\text { Toshiba, Panasonic }\end{array}$ & $\begin{array}{l}\text { Hyundai, LG, Samsung, Kia, } \\
\text { Daewoo }\end{array}$ \\
\hline Leadership in innovations & Multiple Sectors & Multiple Sectors & Technology and Electronics & Technology and Electronics \\
\hline $\begin{array}{l}\text { The most specific differences of } \\
\text { products and services }\end{array}$ & Usability and Convenience & Comfort and Safety & Quality and Functionality & Pricing and Compatibility \\
\hline Innovation policy focus & $\begin{array}{l}\text { Innovative Companies and } \\
\text { Entrepreneurs }\end{array}$ & $\begin{array}{l}\text { Innovative Clusters and } \\
\text { Entrepreneurs }\end{array}$ & $\begin{array}{l}\text { Priority Sectors and } \\
\text { Entrepreneurs }\end{array}$ & $\begin{array}{l}\text { Competitive Sectors and } \\
\text { Entrepreneurs }\end{array}$ \\
\hline $\begin{array}{l}\text { Origin of major innovative } \\
\text { companies }\end{array}$ & Closed Innovations & Closed Innovations & Open Innovations & Open Innovations \\
\hline
\end{tabular}

Table 4: The differences of innovation policy of major export oriented markets.

\begin{tabular}{|c|c|c|c|}
\hline & Innovative economies & $\begin{array}{l}\text { Priority Policies for Bridging and } \\
\text { Developing countries }\end{array}$ & Non-innovative Economies \\
\hline Goals & Long term & Education and Exchange Policy & Short term \\
\hline Knowledge & Progressive & Internet, Technology and R\&D policies & Traditional or Local \\
\hline Technology & Up-to-date & Trade and R\&D policies & Outdated \\
\hline Infrastructure & Developed & Exchange, Technology and R\&D policies & Absent or Elementary \\
\hline Markets & Private Driven & Economic and Privatization Policy & State Driven \\
\hline Human Resources & Advanced & Education, Training and R\&D policies & Elementary \\
\hline Entrepreneurship & $\begin{array}{l}\text { Easy to create, change, support, } \\
\text { reorganize and close }\end{array}$ & Exchange, Education and R\&D policies & Rudimentary and tough for entrepreneurs \\
\hline Legal framework & Open and supporting & Exchange, Education and R\&D policies & Bureaucratic and Corrupted \\
\hline $\begin{array}{l}\text { Product and services, patents, } \\
\text { trademarks }\end{array}$ & Many & $\begin{array}{l}\text { Exchange, Education, Economic, Industry } \\
\text { and R\&D policies }\end{array}$ & Few or absent \\
\hline Export and import per capita & High & $\begin{array}{l}\text { Economic, Trade, Education and R\&D } \\
\text { policies }\end{array}$ & Low \\
\hline Innovation and Inventions & High & $\begin{array}{l}\text { R\&D, Innovation, Education, Science and } \\
\text { Knowledge Management Policies }\end{array}$ & Low \\
\hline
\end{tabular}

Table 5: The comparison of innovative and non-innovative economies and priority policies for bridging and developing countries.

is difficult scenario for Kazakhstan with its low level of infrastructure for innovations. Therefore, Kazakhstan should focus on priority and competitive sectors based on open innovations of leading economies. From there it can develop its own innovations, which can gradually build Kazakhstan's competitive advantage in priority and competitive export oriented sectors.

Allocating the budgets and launching new businesses by state bodies should not ignore existing businesses. Because they are more quick and cost efficient for restructuring businesses and infrastructures for R\&D, especially if they will be trained and upgraded. Their business experience and knowledge are more valuable for policy development and launching new innovative productions. Clustering such innovative entrepreneurs on competitive base and training them effectively for building $\mathrm{R} \& \mathrm{D}$ infrastructure are necessary to provide effective structural changes in economy.

Without proper selection and education of innovative entrepreneurs, the allocation of budgets for various programs is a waste of resources. Because imported technology and knowledge outdate and lose their competitive advantage very soon, especially where no systems for advancing them are available. However, only knowledge can generate new innovative knowledge and therefore policies should focus on development of knowledge management systems for various industries. At the stage of building a business chain of new innovative companies, it is extremely vital to reevaluate knowledge systems and advance them with new information technologies and $R \& D$.

A new economic era of Kazakhstan started in 90s and this is a short period for a country to develop innovations. Many programs which were based on adaptation of the programs of the leading economies was a short term vision of Kazakhstan without proper understanding the scope and origination of those programs for innovations, their history of market and economic theory.

Therefore, the focus of Kazakhstan's Government policy should change from short-term to long-term policies, from short-term macroeconomic policy to long-term innovation policy. Changing the goals are an initial driver for restricting the systems and programs. To understand the models of many leading countries, which are a main source for ideas and policies for growing global markets, the Government should prioritize R\&D as a key component of innovation policy of Kazakhstan.

Exporting of resources when prices are attractive is lucrative but this can destroy plans when prices for natural resources go down. This happened several times and Kazakhstan should learn from this a big lesson to focus and become a leader in championing in innovation policy and achieving its global goals. In addition, nobody can save country from economic collapse if a country cannot adapt its competitive resources for production of value driven products and services in a period of globalization. At this stage, it is important to look for main components of economy and compare them to define priorities for Kazakhstan in policy development.

Table 5 shows an overview of innovative and non-innovative countries and priority policies for bridging and developing countries to build their competitive advantages in a global marketplace.

The Table 5 shows elementary but very important ingredients to focus innovation policy of Kazakhstan to develop its competitive advantages to step in row with the globalization trends. 
Why it is important to focus on globalization trends and export oriented innovations for each country?

From economic point, countries can benefit from competitive advantage in a long run. Because, $R \& D$ will lead to focus on productions of innovations that are more efficient and economical to produce. For businesses, it mean specialization in areas, which will allow them to be more innovative and competitive first on local level and gradually on international one.

$\mathrm{R} \& \mathrm{D}$ will not devaluate if intellectual protection will be on top of the agenda of every country. In any term, Kazakhstan can sell or exchange its innovations if it has a value and meets international demand. And this is how new markets will be created and it will also eliminate all present economic issues in developing countries, especially related to extreme poverty, infrastructure and other areas. For Kazakhstan, it means a new source of income, especially for a country between Europe and Asia, where the nation can become a strong intermediate for exchange of innovations between regions.

The current paper reviewed the innovation policy of Kazakhstan via prism of theories and preliminary analysis. As a key, it aimed to outline general country specific recommendations on innovation policy development of Kazakhstan focusing on strategies and ingredients of innovations. The offered tables and views for innovation policy have been developed based on practical use of innovations and analysis of literature.

Further study is necessary to evaluate the country specific industries of Kazakhstan, which can build their competitive advantage with the support of new state programs. Moreover, to define a strategy on a country level, it is important to organize on a constant level a qualitative and quantitative research of businesses, entrepreneurs and state representatives, who are the objects of innovation policy. On a micro level, a countrywide analysis is required of management systems, export products, innovation infrastructure and $\mathrm{R} \& \mathrm{D}$ operations of private and state organizations.

\section{References}

1. 2010-2014 National program of forced industrial and innovative development of the Republic of Kazakhstan. (2010) Decree of the President of the Republic of Kazakhstan.

2. Astana (2014) The State program on industrial-innovative development of Kazakhstan for 2015-2019. Decree of the President of the Republic of Kazakhstan.

3. World Bank Group (2016) Ease of Doing Business in Kazakhstan. World Bank

4. World Economic Forum (2016) World Competitiveness Index.

5. IMD World (2016) World Competitiveness Rank.

6. Committee of Statists of the Ministry of National Economy of the Republic of Kazakhstan.

7. Innovation and High Technologies in Kazakhstan (2016) Presentation, RFCA Rating Agency.

8. Boyd H, Walker O, Larreche JC (1995) Marketing Management: A Strategic Approach with a Global Orientation. Irwin, 35.

9. Sandefur T (2008) "Innovation." The Concise Encyclopedia of Economics Library of Economics and Liberty.

10. Charles WL (2001) International business: competing in the global marketplace: postscript. (3rdedn) Chapter 4: International Trade Theory, Irwin, MacGrawHill, New York, 50-53. 